\title{
PENGARUH IKLAN DAN KEPERCAYAAN KONSUMEN TERHADAP KEPUTUSAN PEMBELIAN PRODUK LIPSTIK MEREK WARDAH
}

\author{
Suhandi \\ suhandi.binabangsa@gmail.com \\ Program Studi Manajemen Fakultas Ekonomi dan Bisnis Universitas Bina Bangsa
}

\begin{abstract}
Abstrak
Penelitian ini bertujuan untuk mengetahui pengaruh iklan dan kepercayaan konsumen terhadap keputusan pembelian produk lipstik merek Wardah. Populasi dalam penelitian ini mahasiswi Program Studi Manajeen Fakultas Ekonomi dan Bisnis Universitas Bina Bangsa. Penentuan jumlah sampel menggunakan teknik probability sampling diperoleh sebanyak 71 orang sampel. Metode analisis data yang digunakan pada penelitian ini yaitu analisis regresi linier berganda. Hasil pengujian hipotesis pada uji t atau uji parsial menunjukan bahwa variabel iklan berpengaruh positif signifikan terhadap variabel keputusan pembelian. Selanjutnya kepercayaan konsumen berpengaruh positif signifikan terhadap variabel keputusan pembelian. Pengujian hipotesis pada uji simultan menunjukan bahwa iklan dan kepercayaan konsumen berpengaruh positif signifikan terhadap variabel keputusan pembelian.
\end{abstract}

Kata Kunci: Iklan, Kepercayaan Konsumen, Keputusan Pembelian.

\begin{abstract}
This study aims to determine the effect of advertising and consumer trust on purchasing decisions for Wardah brand lipstick products. The population in this study were students of the Management Study Program, Faculty of Economics and Business, Bina Bangsa University. Determining the number of samples using probability sampling techniques obtained as many as 71 samples. The data analysis method used in this study is a multiple linear regression analysis. The results of hypothesis testing on the t-test or partial test show that the advertising variable has a significant positive effect on the purchasing decision variable. Furthermore, consumer confidence has a significant positive effect on purchasing decision variables. Hypothesis testing in the simultaneous test shows that advertising and consumer trust have a significant positive effect on purchasing decision variables.
\end{abstract}

Keywords: Advertising, Consumer Trust, Purchasing Decisions.

\section{PENDAHULUAN}

Saat ini sedang berkembangnya kosmetik berlabel halal. Diperkirakan kosmetik berlabel halal akan segera naik daun, karena beberapa produsen kosmetik dalam negeri maupun luar negeri sudah memiliki setifikat halal di Indonesia. Untuk menghadapi persaingan dalam bisnis kecantikan, perlu adanya penelitian dengan menganalisa terkait pengaruh iklan dan kepercayaan terhadap keputusan sebuah produk, sehingga produk itu mampu bersaing di pasaran. Dalam prespektif iklan cenderung menakankan pada aspek penyampaian pesan yang kreatif dan persuasif yang di sampaikan melalui media khusus. Prspektif pemasaran lebih menekankan pemaknaan iklan sebagai alat pemasaran yaitu menjual produk. Sementara dalam prespektif psikologi lebih menekankan aspek persuasif pesan. Iklan adalah bagian dari bauran promosi (promotion mix) dan bauran promosi adalah bagian dari bauran pemasaran (marketing mix). Secara sederhana iklan didefinisikan sebagai pesan yang menawarkan suatu produk yang ditujukan kepada masyarakat lewat suatu media. Sedangkan periklanan (advertising) adalah segala biaya yang harus dikeluarkan sponsor untuk melakukan presentasi dan promosi nonpribadi dalam bentuk gagasan, barang atau jasa (Kertamukti, 2015).

Wardah menjadi salah satu brand kosmetik berlabel halal yang terkenal di Indonesia. Produk wardah aman untuk kulit karena terbuat dari bahan alami. Hal tersebut penting untuk diperhatikan karena penggunaan langsung pada bibir akan terjilat atau ikut dengan makanan atau minuman yang dimakan sehingga bahan yang digunakan 
harus dipastikan aman. Wardah yang awalnya menarik minat beli berdasarkan sub-agama ini ternyata tidak hanya dinikmati oleh kalangan perempuan muslim dan berhijab saja, namun juga kalangan perempuan non-muslim tertarik dengan produk yang dikeluarkan oleh wardah. Untuk di wilayah Banten sendiri sudah banyak yang menjual kosmetik wardah. Seperti yang kita ketahui bahwa sudah banyak produk kosmetik wardah yang beredar di wilayah Banten yang ada di berbagai toko/ kios kecil, minimarket dan pusat perbelanjaan lainnya.

Kepercayaan adalah kesediaan perusahaan untuk bergantung pada mitra bisnis. Kepercayaan tergantung pada beberapa faktor antar pribadi dan antar organisasi seperti kompetensi, integritas, kejujuran dan kebaikan hati. Membangun kepercayaan bisa menjadi hal yang sulit dalam situasi online, perusahaan menerapkan peraturan ketat kepada mitra bisnis online mereka dibanding mitra lainnya (Susilo, Haryono, \& Mukeri, 2018). Selain itu pula menurut Sutrisno, Cahyono, \& Qomariah (2017), kepercayaan merupakan sebuah keyakinan dari salah satu pihak mengenai maksud dan perilaku yang ditujukan kepada pihak yang lainnya, dengan demikian kepercayaan konsumen didefinisikan sebagai suatu harapan konsumen bahwa penyedia jasa bisa dipercaya atau diandalkan dalam memenuhi janjinya.

PT Paragon Technology and Innovation memperkenalkan produk kosmetik wardah melalui iklan di televisi dengan beragam kreativitas yang diciptakan, melalui iklan dapat menimbulkan persepsi seseorang terhadap produk yang diiklankan. Salah satu iklan yang dimuat di televisi adalah iklan kosmetik wardah Exclusive Series. Iklan Wardah Exclusive Series memiliki unsurunsur dalam pesan iklan yakni isi pesan, struktur pesan, format pesan, dan sumber pesan. Isi pesan yang terkandung di dalam iklan Wardah Exclusive Series yaitu ingin memberikan inspirasi bahwa wanita dalam iklan wardah tersebut, ditampilan tidak hanya sebagai wanita yang cantik saja. Tetapi juga sebagai wanita yang berani, mandiri, energik dan stylish. Bagi wardah, wanita berjilbab tidak membuat wanita tidak tampil gaya, akan tetapi merasa cantik dengan tampilan berhijab yang beda dan menggunakan kosmetik tidak hanya untuk tubuh akan tetapi juga untuk jiwa. Struktur pesan dalam iklan adalah secara keseluruhan dalam iklan tersebut untuk menarik perhatian audiens terhadap ide atau gagasan yang ditawarkan.

Rumusan masalah pada penelitian ini adalah untuk menguji pengaruh iklan dan kepercayaan konsumen terhadap keputusan pembelian produk lipstik merek wardah (studi kasus pada mahasiswi Program Studi Manajemen Fakultas Ekonomi dan Bisnis Universitas Bina Bangsa), Untuk menguji pengaruh kepercayaan konsumen terhadap keputusan pembelian produk lipstik merek wardah (studi kasus pada mahasiswi Program Studi Manajemen Fakultas Ekonomi dan Bisnis Universitas Bina Bangsa), Untuk menguji pengaruh iklan dan kepercayaan konsumen terhadap keputusan pembelian produk lipstik merek wardah (studi kasus pada mahasiswi Program Studi Manajemen Fakultas Ekonomi dan Bisnis Universitas Bina Bangsa).

\section{METODE PENELITIAN}

Jenis penelitian ini adalah jenis penelitian kuantitatif deskriptif. Metode pengumpulan data yang digunakan dalam penelitian ini yaitu metode survai melalui instrumen kusioner dengan memberikan pertanyaan secara terbuka kepada siswi Objek penelitian ini yaitu Mahasiswi Program Studi Manajemen Fakultas Ekonomi \& Bisnis Universitas Bina Bangsa. Berdasarkan tingkat eksplanasinya (tingkat kejelasan) penelitian ini digolongkan kedalam penelitian asosiatif kausal yang merupakan penelitian yang mencari hubungan atau pengaruh sebab akibat yaitu hubungan atau pengaruh variabel bebas $(\mathrm{X})$ terhadap variabel terikat $(\mathrm{Y})$. penelitian bertujuan untuk menguji seberapa jauh pengaruh iklan $\left(\mathrm{X}_{1}\right)$ dan kepercayaan konsumen $\left(\mathrm{X}_{2}\right)$ terhadap keputusan pembelian (Y).

Populasi sebagai wilayah generalisasi yang terdiri atas obyek/subyek yang mempunyai kualitas dan karakteristik tertentu yang ditetapkan oleh peneliti untuk dipelajari dan kemudian ditarik kesimpulannya (Sugiyono, 2018). Populasi yang digunakan dalam penelitian ini adalah Mahasiswi Reguler 1 Angkatan Tahun 2018 Program Studi Manajemen Fakultas Ekonomi dan Bisnis Universitas Bina Bangsa, yang berjumlah 247 orang. Menurut Hamid \& Patra (2019) sampel adalah kumpulan atau bagian dari populasi yang terpilih dengan prosedur tertentu yang bisa merepresentasikan populasi. Penentuan jumlah sampel pada penelitian ini menggunakan teknik probability sampling diperoleh sebanyak 71 orang sampel. Metode analisis yang digunakan yaitu analisis regresi linier berganda.

\section{HASIL DAN PEMBAHASAN}

Berdasarkan pada hasil pengujian validitas dan reliabilitas untuk konstruk iklan $\left(\mathrm{X}_{1}\right)$, kepercayaan konsumen $\left(\mathrm{X}_{2}\right)$, dan keputusan pembelian (Y), seluruh indikator penelitian terkategori valid dan reliabel. Hasil uji validitas menunjukkan bahwa untuk keseluruhan indikator iklan $\left(\mathrm{X}_{1}\right)$, kepercayaan konsumen $\left(\mathrm{X}_{2}\right)$, dan keputusan pembelian (Y) memiliki nilai sig. < 0,05. Hasil uji reliabilitas untuk konstruk iklan $\left(\mathrm{X}_{1}\right)$, kepercayaan konsumen $\left(\mathrm{X}_{2}\right)$, keputusan pembelian (Y) memiliki nilai cronbach's alpha $\geq$ dari koefisien korelasi 0,60 (scale of thumb, nunally).

\section{Uji Asumsi Klasik \\ Hasil Uji Normalitas}

Menurut Hamid, Bachri, Salju, \& Ikbal (2019), tujuan dari uji normalitas yaitu untuk menguji sebuah model regresi dimana variabel pengganggu atau residual memiliki distribusi normal. Berdasarkan hasil analisis untuk uji asumsi klasik normalitas diperoleh informasi pada tabel 1 . 
Tabel 1.

Uji Normalitas

\begin{tabular}{|ll|c|}
\hline & & $\begin{array}{c}\text { Unstandardized } \\
\text { Residual }\end{array}$ \\
\hline Normal Parameters ${ }^{\mathrm{a}, \mathrm{b}}$ & Mean & 71 \\
& Std. Deviation & .0000000 \\
Most Extreme Differences & Absolute & .66415357 \\
& Positive & .110 \\
& Negative & -.074 \\
Test Statistic & & .110 \\
Asymp. Sig. (2-tailed) & & $.033^{\mathrm{c}}$ \\
\hline
\end{tabular}

Berdasarkan tabel diatas dapat diketahui bahwa besarnya nilai Kolmogorov Smirnov Test adalah 0,33 dan signifikan pada 0,10 hasilnya adalah $0,33>0,10$ dapat disimpulkan yaitu nilai residual dari uji normalitas lebih besar dari $10 \%$ maka uji asumsi klasik normalitas terpenuhi atau data pada penelitian ini berdistribusi normal.

\section{Hasil Uji Multikolinearitas}

Uji multikolinieritas bertujuan untuk menguji apakah dalam model regresi ditemukan adanya korelasi yang tinggi atau sempurna antar variabel independent. Jika antar variabel independen $\mathrm{X}$ terjadi multikolinieritas sempurna, maka koefisien regresi variabel $\mathrm{X}$ tidak dapat ditentukan dan nilai standar error menjadi tak terhingga. Jika multikoliniertias antar variabel $\mathrm{X}$ tidak sempurna tetapi tinggi, maka koefisien regresi $\mathrm{X}$ dapat ditentukan, tetapi memiliki nilai standar error tinggi yang berarti nilai koefisien regresi tidak dapat diestimasi dengan tepat (Hamid, Bachri, Salju, \& Ikbal, 2019). Berdasarkan hasil analisis untuk uji asumsi klasik multikolinieritas diperoleh informasi pada tabel 2.

Tabel 2.

Uji Multikolinieritas

\begin{tabular}{|ll|c|c|}
\hline \multirow{2}{*}{\multicolumn{2}{|c|}{ Model }} & \multicolumn{2}{c|}{ Collinearity Statistics } \\
\cline { 2 - 4 } & Tolerance & VIF \\
\hline 1 & (Constant) & & \\
& Iklan & .776 & 1.288 \\
Kepercayaan Konsumen & .776 & 1.288 \\
\hline
\end{tabular}

Dari tabel diatas dapat dilihat bahwa hasil uji multikolinearitas tersebut, diperoleh nilai tolerance $0,776>$ 0,1 dan nilai VIF sebesar $1,288<10$, maka dapat disimpulkan bahwa tidak terjadi multikolinearitas antar variabel independen.

\section{Uji Heteroskedastisitas}

Adanya varian variabel pada model regresi yang tidak sama (konstan) merupakan indikasi adanya gejala heteroskedastisitas. Begitu juga sebalikanya apabila varian variabel pada model regresi memiliki nilai yang sama (konstan) hal ini menandakan adanya indikasi gejala homoskedastisitas. Namun yang diinginkan pada model regresi yaitu adanya gejala homoskedastisitas (Hamid, Bachri, Salju, \& Ikbal, 2019). hasil analisis uji heteroskedastisitas disajikan pada gambar 1.

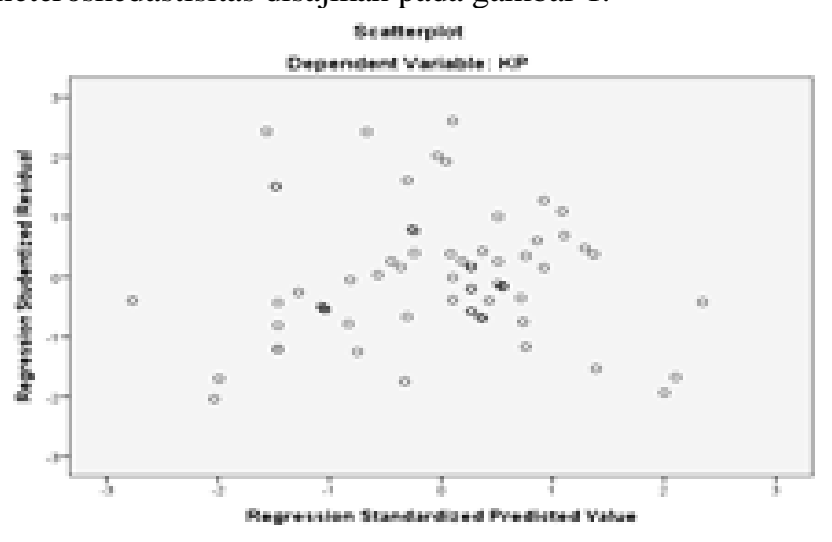

\section{Gambar 1. Uji Heterokdastisitas}

Berdasarkan pada gambar tersebut di atas maka uji heterokdastisitas dihasilkan adalah tidak ada pola yang jelas serta titik-titik menyebar di atas dan di bawah angka 0 pada sumbu Y maka tidak terjadi heteroskedastisitas.

\section{HASIL ANALISIS DATA}

\section{Hasil Analisis Regresi Linier Berganda}

Menurut Sugiyono (2016), analisis regresi linier berganda merupakan regresi yang memiliki satu variabel dependen dan dua atau lebih variabel independen. Berdasarkan hasil pengujian regresi linier berganda tabel 3 , diperoleh informasi mengenai persamaan regresi penelitian.

Tabel 3.

Uji Regresi Linier Berganda

\begin{tabular}{|c|c|c|c|c|c|}
\hline \multirow[b]{2}{*}{ Model } & \multicolumn{2}{|c|}{$\begin{array}{c}\text { Unstandardized } \\
\text { Coefficients } \\
\end{array}$} & $\begin{array}{l}\text { Standardized } \\
\text { Coefficients }\end{array}$ & \multirow[t]{2}{*}{$\mathrm{t}$} & \multirow[t]{2}{*}{ Sig. } \\
\hline & B & Std. Error & Beta & & \\
\hline (Constant) & 10.332 & 3.187 & & 3.242 & .002 \\
\hline Iklan & .320 & .049 & .581 & 6.528 & .000 \\
\hline $\begin{array}{l}\text { Kepercayaan } \\
\text { Konsumen }\end{array}$ & .257 & .078 & .291 & 3.270 & .002 \\
\hline
\end{tabular}

Berdasarkan tabel diatas, dapat dibentuk persamaan sebagai berikut:

$$
\begin{aligned}
& Y=a+b_{1} X_{1}+b_{2} X_{2}+e \\
& Y=10,332+0,320 X_{1}+0,257 X_{2}+e
\end{aligned}
$$

Sesuai dengan persamaan regresi yang diperoleh, maka model regresi tersebut dapat di interprestasikan sebagai berikut:

1. Koefisien konstanta bernilai positif menyatakan bahwa dengan mengasumsikan ketiadaan seluruh variabel independen, maka keputusan pembelian $(\mathrm{Y})$ cenderung mengalami peningkatan sebesar nilai konstanta 10,332.

2. Koefisien regresi iklan $\left(\mathrm{X}_{1}\right)$ bernilai positif menyatakan bahwa dengan mengasumsikan ketiadaan variabel 
independen lainnya maka iklan $\left(\mathrm{X}_{1}\right)$ mengalami kenaikan 1 point maka iklan $\left(\mathrm{X}_{1}\right)$ cenderung mengalami peningkatan sebesar 0,320 terhadap Keputusan Pembelian (Y).

3. Koefisien regresi kepercayaan konsumen $\left(\mathrm{X}_{2}\right)$ bernilai positif menyatakan bahwa dengan mengasumsikan ketiadaan variabel independen lainnya maka kepercayaan konsumen $\left(\mathrm{X}_{2}\right)$ mengalami kenaikan 1 point maka kepercayaan konsumen $\left(\mathrm{X}_{2}\right)$ cenderung mengalami peningkatan sebesar 0,257 terhadap Keputusan Pembelian (Y).

\section{Hasil Koefisien Determinasi $\left(\mathbf{R}^{2}\right)$}

Berdasarkan hasil analisis diperoleh informasi nilai koefisien determinasi yang disajikan pada tabel 4 .

Tabel 4.

Koefisien Determinasi

\begin{tabular}{|c|c|c|c|c|}
\hline & & $\mathrm{R}$ & Adjusted R \\
Model & $\mathrm{R}$ & Square & $\begin{array}{c}\text { Std. Error of the } \\
\text { Estimate }\end{array}$ \\
\hline 1 & $.763^{\mathrm{a}}$ & .582 & .570 & 2.70305 \\
\hline
\end{tabular}

Dari output model summary diatas, diperoleh keterangan bahwa kontribusi hubungan antara faktor iklan $\left(\mathrm{X}_{1}\right)$ dan kepercayaan konsumen $\left(\mathrm{X}_{2}\right)$ dengan keputusan pembelian (Y) sebesar 58,20\% dan 41,80\% sisanya dipengaruhi oleh faktor lain yang tidak diteliti oleh penulis. Adapun faktor lain seperti harga, kualitas produk, citra merek, brand image dan lain sebagainya.

\section{Hasil Uji t (Parsial)}

Berdasarkan tabel output tabel 3, dapat diketahui bahwa nilai koefisien regresi variabel iklan $\left(X_{1}\right)$ adalah sebesar 0,320 bernilai positif (+), dengan begitu dapat disimpulkan bahwa iklan $\left(\mathrm{X}_{1}\right)$ berpengaruh secara signifikan terhadap keputusan pembelian (Y). Nilai sig $0,000<0,10$. thitung $_{\text {h }}$ $6,528>1,667 \mathrm{t}_{\text {tabel. }}$. Maka $\mathrm{H}_{0}$ ditolak dan $\mathrm{H}_{\mathrm{a}}$ diterima, artinya terdapat pengaruh yang signifikan antara kklan $\left(\mathrm{X}_{1}\right)$ terhadap keputusan pembelian (Y). Berdasarkan tabel output tabel 3, diketahui bahwa nilai koefisien regresi variabel kepercayaan konsumen $\left(\mathrm{X}_{2}\right)$ adalah sebesar 0,257 bernilai positif $(+)$, sehingga dapat dikatakan kepercayaan konsumen $\left(\mathrm{X}_{2}\right)$ berpengaruh positif terhadap keputusan pembelian (Y). Nilai sig $0,002<0,10$. $t_{\text {hitung }} 3,270>1,667$ $\mathrm{t}_{\text {tabel. }}$ Maka $\mathrm{H}_{0}$ ditolak dan $\mathrm{H}_{\mathrm{a}}$ diterima, artinya ada pengaruh yang signifikan antara kepercayaan konsumen $\left(\mathrm{X}_{2}\right)$ terhadap keputusan pembelian (Y).

\section{HASIL UJI F (Simultan)}

Berdasarkan hasil analisis data penelitian diperoleh informasi nilai untuk uji $\mathrm{F}$ atau pengujian secara simultan varaibel bebas terhadap variabel terikat dalam penelitian. Hasil uji dapat dilihat pada tabel 5.
Tabel 5.

Uji F

\begin{tabular}{|ll|c|c|c|c|c|}
\hline \multicolumn{1}{|c|}{ Model } & $\begin{array}{c}\text { Sum of } \\
\text { Squares }\end{array}$ & Df & $\begin{array}{c}\text { Mean } \\
\text { Square }\end{array}$ & F & Sig. \\
\hline 1 & Regression & 691.949 & 2 & 345.974 & 47.352 & $.000^{\mathrm{b}}$ \\
& Residual & 496.840 & 68 & 7.306 & & \\
Total & 1188.789 & 70 & & & \\
\hline
\end{tabular}

Setelah dilakukan uji $\mathrm{F}$, diperoleh $\mathrm{F}_{\text {hitung }}=47,352$ sedangkan nilai $\mathrm{F}_{\text {tabel }}(\mathrm{df}=\mathrm{n}-\mathrm{k}-1=71-2-1=68)$ sebesar 3,130 dengan taraf nyata sebesar $0,10 \mathrm{~F}_{\text {hitung }}>\mathrm{F}_{\text {tabel }}$ $(47,352>3,130)$ dengan demikian $\mathrm{H}_{0}$ ditolak dana $\mathrm{H}_{1}$ diterima dengan tingkat signifikansi sebesar $0,000(0,000<$ $0,10)$. Terdapat pengaruh yang signifikan antara iklan $\left(\mathrm{X}_{1}\right)$ dan kepercayaan konsumen $\left(\mathrm{X}_{2}\right)$ terhadap keputusan pembelian (Y).

\section{PEMBAHASAN HASIL PENELITIAN}

Pengaruh Iklan terhadap Keputusan Pembelian

Setelah dilakukan pengujian dan analisis hipotesis diketahui terdapat pengaruh yang signifikan antara iklan $\left(\mathrm{X}_{1}\right)$ terhadap keputusan pembelian (Y) pada produk lipstik merek Wardah. Dalam uji t dapat dilihat bahwa $t_{\text {hitung }}>t_{\text {tabel }}$ $(6,528>1,667)$ dengan tingkat signifikansi sebesar $(0,000$ $<0,10$ ) dengan begitu dapat disimpulkan bahwa terdapat pengaruh yang signifikan antara iklan $\left(\mathrm{X}_{1}\right)$ terhadap keputusan pembelian (Y) pada produk lipstik merek Wardah.

Hasil temuan penelitian ini sejalan dengan hasil temuan penelitian yang dilakukan oleh Pawitri \& Sholeha (2019), promosi berpengaruh positif signifikan terhadap keputusan pembelian. Hasil penelitian ini memberikan bukti bahwa iklan atau promosi produk lipstik Wardah dipersepsikan dengan baik oleh responden. Mereka menganggap bahwa iklan atau promosi telah sesuai dengan apa yang mereka butuhkan.

\section{Pengaruh Kepercayaan Konsumen terhadap Keputusan Pembelian}

Hasil analisis untuk uji parsial variabel kepercayaan konsumen, yakni terdapat pengaruh yang signifikan antara kepercayaan konsumen $\left(\mathrm{X}_{2}\right)$ terhadap keputusan pembelian (Y) pada produk lipstik merek Wardah. Pada uji t dapat diketahui hasil $t_{\text {hitung }}>t_{\text {tabel }}(3270>1,667)$ dengan tingkat signifikansi sebesar $0,002<0,10$. Maka dapat disimpulkan bahwa terdapat pengaruh yang signifikan antara kepercayaan konsumen $\left(\mathrm{X}_{2}\right)$ terhadap keputusan pembelian (Y) pada produk lipstik merek Wardah.

Terdapat pengaruh yang signifikan pada iklan $\left(\mathrm{X}_{1}\right)$, kepercayaan konsumen $\left(\mathrm{X}_{2}\right)$ terhadap keputusan pembelian (Y) pada produk lipstik merek Wardah. dapat dilihat hasil $\mathrm{F}_{\text {hitung }}>\mathrm{F}_{\text {tabel }}(47,352>3,130)$ dengan demikian $\mathrm{H}_{0}$ ditolak dan $\mathrm{H}_{3}$ diterima dengan tingkat signifikansi $0,000<0,10$. Dengan demikian dapat disimpulkan terdapat pengaruh yang signifikan antara iklan $\left(\mathrm{X}_{1}\right)$ dan kepercayaan konsumen $\left(\mathrm{X}_{2}\right)$ terhadap keputusan pembelian (Y) pada 
produk lipstik merek Wardah. Hasil temuan ini sejalan dengan hasil temuan penelitian yang dilakukan oleh (Meliana, Sulistiono, \& Setiawan, 2013), kepercayaan konsumen berpengaruh positif signifikan terhadap keputusan pembelian.

\section{PENUTUP}

\section{Simpulan}

Berdasarkan hasil analisis dan pembahasan pada Pengaruh Iklan dan Keputusan Pembelian terhadap Keputusan Pembelian Lipstik Merek Wardah, peneliti menarik kesimpulan yaitu:

1. Terdapat pengaruh Iklan $\left(\mathrm{X}_{1}\right)$ terhadap Keputusan Pembelian (Y) pada Lipstik Merek Wardah, artinya terdapat pengaruh positif signifikan antara iklan $\left(\mathrm{X}_{1}\right)$ dengan keputusan pembelian (Y).

2. Terdapat pengaruh positif signifikan antara kepercayaan konsumen $\left(\mathrm{X}_{2}\right)$ dengan keputusan pembelian $(\mathrm{Y})$.

3. Terdapat pengaruh Iklan $\left(\mathrm{X}_{1}\right)$ dan Kepercayaan Konsumen $\left(\mathrm{X}_{2}\right)$ terhadap Keputusan Pembelian (Y) pada Lipstik Merek Wardah, maka dapat disimpulkan bahwa kedua variabel independent yaitu Iklan dan Kepercayaan Konsumen secara signifikan keduanya memberikan peranan penting terhadap variabel Keputusan Pembelian dan masuk dalam kategori "kuat".

\section{Saran}

Berdasarkan pembahasan hasil analisis dan simpulan, penulis mengusulkan beberapa saaran diantaranya yaitu:

1. Perusahaan perlu meningkatkan iklan untuk mempertahankan konsumen, karena iklan yang menarik akan menimbulkan keputusan pembelian pada suatu produk. Perusahaan perlu mempertahankan kualitas produk lipstik merek wardah karena kualitas produk yang baik dapat membuat konsumen percaya akan produk lipstik tersebut sehingga mendorong untuk melakukan pembelian ulang pada produk yang sama.

2. Peneliti selanjutnya disarankan untuk meneliti perusahaan lain yang sejenis dengan iklan dan kepercayaan konsumen lainnya yang mungkin mengalami permasalahan yang hampir sama. Dengan mengambil contoh iklan dan kepercayaan konsumen produk lipstik lain, maka permasalahan yang dialami dalam pengaruh iklan dan kepercayaan konsumen terhadap keputusan pembelian tersebut tentu juga berbeda. Hal ini dapat dijadikan bahan pembanding sekaligus melengkapi penelitian ini.

3. Peneliti selanjutnya disarankan untuk mencari ruang lingkup populasi yang berbeda dan lebih luas dari populasi dalam penelitian ini. Sampel yang digunakan sebaiknya juga lebih banyak dari pada sampel dalam penelitian ini, dengan demikian penelitian selanjutnya dapat memberikan gambaran yang lebih spesifik mengenai pengaruh iklan dan kepercayaan konsumen terhadap keputusan pembelian. Penelitian selanjutnya juga dapat meneliti faktor-faktor lain yang dapat mempengaruhi keputusan pembelian selain faktor dari Iklan dan Kepercayaan konsumen. Adapun faktor lain seperti harga, kualitas produk, citra merek, brand image dan lain sebagainya.

\section{DAFTAR PUSTAKA}

Hamid, R. S., \& Patra, I. K. (2019). PENGANTAR STATISTIKA UNTUK RISET BISNIS DAN EKONOMI Konsep Dasar dan Aplikasi SPSS versi 25. Banten: CV. AA. RIZKY.

Hamid, R. S., Bachri, S., Salju, S., Ikbal, M. (2019). Panduan Praktis Ekonometrika Konsep Dasar dan Penerapan Menggunakan Eviews 10. Banten: CV. AA. RIZKY.

Kertamukti, R. (2015). Strategi kreatif dalam periklanan. Jakarta: Raja Grafindo Persada.

Metode Penelitian Kuantitatif \& kualitatif, Journal of Experimental Psychology: General (2010).

Meliana, M., Sulistiono, S., \& Setiawan, B. (2013). Pengaruh Kualitas Pelayanan dan Kepercayaan Konsumen Terhadap Keputusan Pembelian. Jurnal Ilmiah Manajemen Kesatuan, 1(3), 247-254.

Pawitri, N. E., \& Sholeha, M. (2019). PENGARUH PROMOSI DAN INOVASI PRODUK TERHADAP KEPUTUSAN PEMBELIAN HONDA MOBILIO (Survei Pada Pengguna Honda Mobilio di Karawang). Jurnal Manajemen STIE Muhammadiyah Palopo, 5(2), 34-41.

Sugiyono. (2016). Definisi dan Operasionsl Variabel Penelitian. Definisi Dan Operasionsl Variabel Penelitian.

Susilo, H., Haryono, A. T., \& Mukeri, M. (2018). Analisis pengaruh harga, kualitas pelayanan, promosi, dan kepercayaan terhadap kepuasan konsumen dengan keputusan berkunjung sebagai variabel intervening di Hotel Amanda Hills Bandungan. Journal of Management, 4(4).

Sutrisno, Cahyono, D., \& Qomariah, N. (2017). ANALISIS KUALITAS PELAYANAN, KEPERCAYAAN SERTA CITRA KOPERASI TERHADAP KEPUASAN DAN LOYALITAS ANGGOTA. Jurnal Sains Manajemen \& Bisnis Indonesia. 